Jurnal Lakon, 5 (1) 2016

$(1-14)$

\title{
POLITIK SEKSUAL DALAM NOVEL LEMAH TANJUNG, PECINAN KOTA MALANG, DAN 1998 KARYA RATNA INDRASWARI IBRAHIM
}

Sexual Politics in Ratna Indraswari Ibrahim's Lemah Tanjung, Pecinan Kota Malang, and 1998 Novel

\section{YUNI KUSWIDARTI}

\author{
Sekolah Menengah Pertama Negeri 2 Pare \\ Jl. Pahlawan Kusuma Bangsa No. 2 Pare \\ e-mail: yunikusw@gmail.com
}

\begin{abstract}
In the radical feminist movement, one well-known slogan is that "the personal is political". Politics here are not only working within the scope of such a large state, but starting from small scope, like family. The research found other forms of sexual politics that occured in the era of the New Order (Orde Baru) in novel Lemah Tanjung, Pecinan Kota Malang, and 1998 by Ratna Indraswari Ibrahim using the concept of Kate Millet. The presence of sexual politics that oppress women leads them to conduct negotiations over the patriarchal system which is deeply embedded in society.
\end{abstract}

Keywords: New Order (Orde Baru), Novel, Patriarchal, Sexual Politics, Women

\begin{abstract}
Abstrak: Pada pergerakan feminis radikal, satu slogan yang terkenal adalah "the personal is political". Politik yang dimaksud tidak hanya beroprasi pada lingkup Negara namun bermula dari lingkup kecil seperti keluarga. Peneliti menemukan adanya bentuk- bentuk politik seksual pada era Orde Barudalam Novel Lemah Tanjung, Pecinan Kota Malang, dan 1998 karya Ratna Indraswari Ibrahim menggunakan konsep Kate Millet. Hadirnya politik seksual yang mengopresi perempuan menyebabkan adanya negosiasi terhadap sistem patriarki yang telah mengakar dalam masyarakat.
\end{abstract}

Kata-kata Kunci: Novel, Orde Baru, Patriarki, Perempuan, Politik Seksual

\section{PENDAHULUAN}

Karya sastra tidak hanya dipandang sebagai imajinasi pengarang semata. Herder dan Immanuel Kant memiliki pendapat yang saling mendukung dalam memandang karya sastra. Menurut Kant, kesesuaian karya sastra dengan alam, sejarah, dan psikologi merupakan suatu kriteria keindahan karya sastra. Sedangkan, menurut Herder setiap karya sastra lahir dari lingkungan sosial dan geografi, sehingga karya sastra kemudian dapat dinilai sekaligus dilihat sebagai referensi sejarah (Swingewood dan Laurenson, 1971).
Karya sastra yang dianggap sebagai dokumen sosial merupakan salah satu alternatif bagi pengarang untuk turut berperan dalam menyumbangkan segala pandangan serta pemikirannya atas permasalahan yang terjadi di masyarakat. Salah satu permasalahan di Indonesia yang banyak diangkat dalam karya sastra adalah kondisi sosial Politik di Era Orde Baru. Berakhirnya Orde Baru yang otoriter memicu para pengarang, termasuk perempuan pengarang untuk berani "bersuara" melalui tulisan-tulisan mereka. Hal ini ditandai dengan munculnya perempuan-perempuan pengarang dalam dunia sastra Indonesia yang melihat kondisi

Jurnal Lakon: Kajian Sastra dan Budaya e-ISSN: 2527-4899; p-ISSN 2252-8954 
sosial politik melalui "kaca mata" perempuan dalam karya-karya mereka pada saat itu, seperti Ayu Utami, Dee Lestari, Fira Basuki, Laksmi Pamuntjak, Djenar Maesa Ayu, Titis Basono, Abidah El Khalieqy, dan lain-lain.

Karya sastra yang diproduksi oleh perempuan pengarang pasca-Soeharto memberikan kontribusi yang cukup signifikan untuk memikirkan ulang sebuah negara. Setelah Orde Baru runtuh dan kehilangan legitimasinya, karya-karya baru perempuan mulai mengeksplorasi berbagai alternatif untuk berbicara, mengajukan persyaratan, dan jika mungkin "mendefinisikan ulang" bangsa, dengan memperhatikan perspektif dan menjabarkan pengalaman perempuan yang terkait dengan perdebatan itu. Para perempuan pengarang menyadari bahwa wacana kekuasaan negara yang telah ditanamkan oleh Orde Baru tidak hanya menekan heterogenitas, namun terutama juga memarjinalkan perempuan. Sehingga, meskipun ini adalah cara yang amat menantang dan terjadi banyak masalah di awal mereka tetap berkontribusi secara mendalam untuk melakukan pemeriksaan ulang dari ideologi kekuasan di era persatuan, gender, ras, kelas, dan kebangsaan (Michalik \& Budianta, 2015).

Dari sekian banyak perempuan pengarang yang muncul pada masa itu, salah satu perempuan pengarang Indonesia yang cukup produktif dan telah mengeluarkan banyak karya sastra adalah Ratna Indraswari Ibrahim. Selain sebagai pengarang, ia dikenal aktif dalam berbagai organisasi sosial, termasuk organisasi perempuan. Pada awalnya, Ratna Indraswari Ibrahim lebih dikenal sebagai cerpenis. Ia telah menerbitkan kurang lebih 400 cerpen dalam bentuk buku kumpulan cerpen, maupun tersebar di media massa. Namun, karena keaktifannya dalam menulis, ia pun telah menghasilkan beberapa novel. Tema-tema yang diangkat oleh Ratna dalam cerpen maupun novelnya adalah seputar permasalahan perempuan. Karya-karyanya seringkali dipilih sebagai bahan kajian oleh para peneliti maupun mahasiswa dari perspektif feminis. Arimbi (2009) menjelaskan bahwa Ratna Indraswari Ibrahim mempercayai karyakarya yang ditulisnya dapat mendukung gerakan perempuan, karena karya-karya tersebut juga berfungsi sebagai salah satu perlawanan untuk maskulinitas yang telah mengakar di Indonesia. Menurut Ratna, bias ideologi patriarki telah berdampak cukup besar pada sistemsistem yang berlaku di negara Indonesia. Sehingga, negara seakan- akan hadir untuk mewakili laki-laki, sedangkan perempuan menjadi masyarakat yang "diam" dan dianggap kelompok marjinal.

Peneliti menemukan hal-hal yang menarik berdasarkan pembacaan awal atas tiga novel Ratna Indraswari Ibrahim, yakni Lemah Tanjung, Pecinan Kota Malang, dan 1998. Pertama, Ratna Indraswari Ibrahim menawarkan setting waktu pada masa Orde Baru dalam tiga novelnya dari beberapa sisi yang menunjukkan bahwa permasalahan pada era Orde Baru begitu kompleks, hingga berpengaruh pada etnisitas, sosial, ekonomi, maupun politik. Kedua, tokohtokoh dan permasalahan yang dimunculkan oleh Ratna Indraswari Ibrahim berasal dari daerah (lokal) yaitu Malang, Jawa Timur, akan tetapi apa yang dirasakan dan dipikirkan oleh para tokoh perempuannya dapat dikatakan mewakili perempuan Indonesia secara umum. Ketiga, jika beberapa pengarang memunculkan tokoh "korban" yang menerima diskriminasi di masa Orde Baru secara langsung, Ratna 
Indraswari Ibrahim justru menampilkan beberapa tokoh yang berada di sekitar "korban". Hal ini menunjukkan bahwa dalam ketiga novelnya, Ratna memperlihatkan dampak sosial politik Era Orde Baru telah diterima oleh masyarakat secara menyeluruh. Keempat, jika dibandingkan dengan novel-novel perempuan pengarang lain di masa reformasi (misalnya, karya-karya sastra wangi yang dikenal mengeksplorasi seksualitas perempuan) tiga novel Ratna Indraswari Ibrahim memang terlihat "kurang berani", akan tetapi novel Lemah Tanjung, Pecinan Kota Malang, dan 1998 sangat realistis dalam menggambarkan kegalauan mayoritas perempuan pada masa itu, yaitu antara kepasrahan dan keinginan untuk melawan dalam keterbatasan. Kelima, keaktifan Ratna Indraswari Ibrahim dalam beberapa organisasi sosial yang memungkinkan karya- karyanya disusun berdasarkan seminar- seminar yang pernah ia ikuti, penelitian- penelitian, atau pun memanfaatkan data- data empiris lainnya.

Berdasarkan latar belakang tersebut, peneliti melakukan penelitian berjudul "Politik Seksual dalam novel Lemah Tanjung, Pecinan Kota Malang, dan 1998 karya Ratna Indraswari Ibrahim". Hal ini karena, meskipun telah banyak karya-karya lain Ratna Indraswari Ibrahim yang telah dikaji dengan menggunakan kritik sastra feminis, akan tetapi belum ada penelitian yang menggunakan konsep politik seksual. Konsep politik seksual (Sexual Politics) Kate Millet dianggap penting dan sesuai untuk dimanfaatkan dalam penelitian novel-novel Ratna Indraswari Ibrahim karena konsep ini menelusuri adanya relasi kuasa antara laki-laki dan perempuan dari berbagai institusi pendukung patriarki yang multidimensional sekaligus menemukan bentuk-bentuk negosiasi yang dilakukan oleh tokoh-tokoh perempuan. Konsep politik seksual lahir ketika Kate Millet menemukan bentuk-bentuk politik seksual dari pengkajiannya terhadap novel-novel laki-laki yang sangat patriarkal. Meskipun demikian, peneliti memanfaatkan model penelitian politik seksual Kate Millet untuk meneliti novelnovel Ratna Indraswari Ibrahim yang umumnya bernafaskan feminis. Hal ini karena, penelitian ini justru dapat digunakan untuk melihat sejauh mana sistem patriarki beroperasi dalam menempatkan perempuan pada posisi subordinat bahkan setelah perempuan melakukan negosiasi.

Berdasarkan latar belakang yang telah dipaparkan, maka peneliti merumuskan permasalahan dalam penelitian ini, yaitu bagaimanakah politik seksual digambarkan dalam novel "Lemah Tanjung", "Pecinan Kota Malang", dan "1998" karya Ratna Indraswari Ibrahim dan bagaimanakah bentuk-bentuk negosiasi tokoh perempuan terhadap politik seksual dalam novel-novel tersebut.

\section{LANDASAN TEORI}

Penelitian ini menggunakan teori kritik sastra feminis dan memanfaatkan model pengkajian politik seksual dari Kate Millet. Selain itu, penelitian ini juga memperhatikan kondisi sosial politik era Orde Baru. Barry (2010) menyatakan bahwa feminisme sejak awal memang memiliki kepedulian krusial terhadap buku dan sastra, karena kaum feminisme menyadari bahwa citra perempuan telah banyak disebarluaskan melalui karya sastra, sehingga kemudian diperlukan perlawanan serta mempertanyakan otoritas dan koherensinya. 
Kritik sastra feminis memiliki tujuan untuk meningkatkan kesadaran peran perempuan dalam aspek produksi sastra sekaligus untuk mengungkapkan sejauh mana laki-laki mendominasi perempuan di berbagai aspek (Carter, 2006). Hal ini karena, kritik sastra feminis akan memperlihatkan adanya pengaruh budaya patriarki dalam kehidupan seharihari dengan melakukan penelitian teks. Menurut Barker (2004), patriarki merupakan sistem tatanan sosial yang terus menerus berulang, yaitu dominasi laki-laki atas subordinasi perempuan di berbagai sosial praktis. Budaya patriarki yang telah mengakar di masyarakat inilah yang menciptakan opresi terhadap perempuan.

\section{Politik Seksual}

Dalam gerakan feminisme radikal atau feminisme gelombang kedua sangat dikenal sebuah slogan, yaitu "the personal is political" yang dikatakan mampu menjangkau persoalan perempuan hingga ke ranah privat. Politik dapat beroperasi secara terselubung sekaligus mengemuka. Hal itu dilakukan sebagai usaha untuk menyalurkan kehendak kuasa laki-laki terhadap perempuan. Politik di sini tidak hanya bekerja dalam lingkup besar seperti negara melainkan dimulai dari lingkup kecil, seperti keluarga. Persoalan politik berselubung kekuasaan terhadap perempuan tidak hanya meliputi perepresian perempuan dalam memiliki hak suara politik dan hak ikut serta dalam keterwakilan politik, melainkan ikut masuk dalam ketubuhan itu sendiri.

Politik Seksual merupakan pemikiran Kate Millet yang dibahas dalam bukunya yang berjudul Sexual Politics (1970). Kate Millet adalah salah satu tokoh feminis radikal-libertarian yang berpendapat bahwa sistem seks/gender di dalam patriarki merupakan akar dari opresi yang dialami oleh perempuan. Menurut Millet, Patriarkal cenderung membesarbesarkan perbedaan biologis antara lakilaki dan perempuan, dan memastikan bahwa laki-laki adalah maskulin dan selalu lebih dominan sedangkan perempuan sebagai feminin mempunyai peran yang subordinat. Karena begitu kuatnya ideologi ini, sehingga perempuan seakan-akan harus menerima opresi tersebut (Tong, 2006).

Politik seksual merupakan hubungan kekuasaan antara laki-laki dan perempuan sebagai dampak dari perbedaan seksual yang dipengaruhi oleh sistem patriarki yang telah mengakar kuat di masyarakat. Sehingga dalam masyarakat patriarki, perempuan memiliki status sebagai kelompok minoritas, yaitu sekelompok manusia yang diperlakukan secara berbeda dengan masyarakat yang lain karena kondisi fisik atau sifat budayanya. Millet menuliskan "...sex is a status category with political implications (2000)", ia menganggap seks sebagai kategori status yang memiliki implikasi politik.

Penelitian ini menerapkan model pengkajian Kate Millet terhadap novel, yaitu dengan menelusuri munculnya politik seksual dari institusi-institusi yang telah melanggengkan sistem patriarki di masyarakat Akan tetapi, karena novelnovel Ratna Indraswari Ibrahim selalu memunculkan semangat perjuangan tokohtokoh perempuan di dalamnya, maka selain menemukan bentuk-bentuk politik seksual, dalam penelitian ini akan ditemukan pula bentuk-bentuk negosiasi yang dilakukan oleh tokoh-tokoh perempuan untuk melawan patriarki. Berikut ini institusiinstitusi pendukung patriarki yang beroperasi dengan saling terkait dan saling 
mempengaruhi dalam mengukuhkan sistem patriarki (2000).

Ideologis. Politik seksual menyosialisasikan sistem patriarki dengan pembentukan temperamen, peran, dan status pada laki-laki dan perempuan.

Biologis. Promosi politik seksual, melalui ilmu religi dan ilmu sains popular, pandangan bahwa perbedaan biologis meningkatkan perbedaan sosial, dimana gender merupakan reifikasi seks daripada suatu konstruksi sosial dan kultural yang dapat ditampilkannya

Sosiologis. Originalisasi politik sosial merupakan bagian yang menetapkan pola general dominasi pria dan pimpinan agensi sosialisasi gender. 7 Sosialisasi terutama dilakukan dalam ranah keluarga yang pada akhirnya akan menyebar ke masyarakat luas.

Kelas. Menempatkan perempuan "di bawah" laki-laki, darimana pun kelas sosial mereka berada. Menciptakan adanya pertentangan antara perempuan yang satu dengan perempuan- perempuan lain.

Ekonomi dan pendidikan. Pekerjaan domestik perempuan tidak mendapatkan bayaran dan seringkali tidak dianggap sebagai pekerjaan, dimana pekerjaan mereka dalam pandangan publik adalah tidak dibayar, mendapatkan diskriminasi dan eksploitasi. Wanita diarahkan dan didorong ke level yang lebih rendah pada performa dan pada spesialisasi pendidikan yang kurang dapat dijual.

Paksaaan. Patriarki didukung oleh koersi legal dan dengan ancaman serta fakta kekuatan informal dengan adanya pemerkosaan dan kekerasan dalam rumah tangga.
Mitos dan agama. Dalam hal ini agama Kristen yang mengajarkan peranan Eva sebagai sumber dari penderitaan manusia, menghubungkan wanita dengan seks dan dosa, mencemari rayuan wanita dan mendorong pria untuk terayu.

Psikologis. Untuk dapat mengatasinya, wanita harus menerima karakteristik personal yang inferior, mereka harus merendahkan diri, menjadikan diri mereka bawahan, merayu pria, menerima standar ganda seksual, melengkapi perilaku mereka dengan intuisi, emosi dan insting daripada intelektual dan menerima perilaku yang terus menerus sebagai obyek seksual.

\section{Sosial Politik dan Politik Seksual Era Orde Baru}

yang turut membentuk serta melanggengkan ideologi patriarkal dalam masyarakat. Pemerintah Orde Baru telah membuat beberapa konsep yang dianggap merugikan perempuan, seperti "Ibuisme negara" yang mengandung unsur-unsur "pengiburumahtanggaan" dan "ibuisme" yang mengarah pada "domestikasi". Paham "ibuisme" mengharuskan perempuan untuk melayani suami, anakanak, keluarga, dan negara. Sedangkan dengan "pengiburumahtanggaan" mereka diharuskan untuk bersedia bekerja tanpa dibayar atau kalaupun dibayar, mereka akan dibayar dengan upah yang rendah. Dan untuk membendung dan memanipulasi kekuatan perempuan secara sosial, politik, maupun ekonomi, pemerintah Orde Baru berupaya mendefinisikan mereka dalam kategori utama sebagai "istri" yang pada akhirnya menciptakan budaya "ikut suami" (Suryakusuma, 2011). 
Selain itu, pemerintah juga menyebarkan ideologi "bapak-ibuisme" pada seluruh lapisan masyarakat bertujuan untuk mendukung "asas kekeluargaan" dalam Pancasila yang pada masa itu sangat digaungkan. Disini "bapak" adalah sumber utama kekuasaan sementara "ibu" merupakan salah satu "mediator" kekuasaan tersebut, sehingga programprogram pembangunan negara dapat terealisasi dengan baik. Kebijakankebijakan pemerintah yang berujung pada politik seksual ini telah dirancang dengan begitu rapi oleh negara, sehingga tidak banyak masyarakat yang menyadari bahwa perempuan telah disubordianasi.

Suryakusuma (2011) menjelaskan bahwa perempuan mendapatkan "peran ganda" yang berarti mendapatkan "beban ganda", yaitu dengan mengharuskan mereka untuk "berpartisipasi" dalam pembangunan negara sekaligus tidak boleh meninggalkan "kodrat" mereka sebagai pencipta keluarga yang bahagia dan sejahtera. Maka, politik seksual dalam kondisi negara yang menindas ini secara terus-menerus mempersempit pilihan perempuan sebagai individu.

Selain permasalahan yang telah dipaparkan di atas, masa Orde Baru juga lekat dengan permasalahan sentimen rasial yang menimpa etnis Tionghoa. Pada saat itu, masyarakat peranakan Tionghoa dianggap sebagai "liyan" oleh masyarakat pribumi. Kehadiran mereka selalu distigmakan negatif. Dari sinilah maka muncul kebencian dan kecemburuan dari masyarakat pribumi yang akibatnya orangorang etnis Tionghoa seringkali dijadikan kambing hitam (scapegoating) dalam permasalahan negara. Termasuk dalam kerusuhan-kerusuhan yang terjadi pada Mei 1998 (Suryadinata, 2002).
Pada peristiwa kerusuhan Mei 1998, etnis Tionghoa banyak mendapatkan kerugian, baik secara psikis, fisik, maupun materi. Rumah- rumah dan toko-toko mereka dibakar dan dijarah, mereka menerima kekerasan, ancaman, siksaan, pelecehan, bahkan pembunuhan. Terlebih lagi, banyak terjadi pemerkosaan pada perempuan-perempuan etnis Tionghoa tanpa alasan yang jelas. Menurut Suryadinata (2002) di Indonesia, perempuan Tionghoa dapat dikatakan menempati posisi double minority, yaitu sebagai perempuan dan sebagai etnis Tionghoa. Hal ini, tentu membuat perempuan-perempuan etnis Tionghoa merasa tidak aman dan tertekan.

Masa Orde Baru yang berakhir pada Mei 1998 menawarkan reformasi sebagai jalan terang dari kebungkaman sekaligus kerusuhan masyarakat. Sejak hadirnya era Reformasi, masyarakat lebih berani untuk "bersuara" bahkan dengan lantang untuk memprotes ketidakadilan. Hal ini juga berlaku bagi para perempuan Indonesia. Mereka banyak mendirikan organisasiorganisasi yang memikirkan nasib perempuan di masa depan yang diharapkan dapat terbebas dari opresi dan subordinasi.

\section{METODE PENELITIAN}

Penelitian ini menggunakan pendekatan kualitatif-deskriptif. Hal ini karena pendekatan kualitatif dapat memberi penjelasan yang luas mengenai perilaku dan kebiasaan manusia. Creswell (2009) yang menyatakan bahwa pendekatan kualitatif sebagai pendekatan yang menyediakan suatu sudut pandang untuk membentuk tipe- tipe pertanyaan, menjelaskan bagaimana data diperoleh, 
menganalisis data, serta memberi ruang untuk sebuah ajakan perubahan.

Dalam penelitian ini, peneliti melakukan interpretasi, mencoba memahami atau menafsirkan makna dari fenomena-fenomena di dunia yang terjadi di dalam teks sastra, yaitu novel- novel Ratna Indraswari Ibrahim. Untuk mendukung analisis dalam penelitian ini, peneliti menggunakan teori kritik sastra feminis.

Dalam penelitian ini, ada dua jenis data, yaitu data primer dan data sekunder. Data primer dalam penelitian ini adalah novel-novel tersebut adalah Lemah Tanjung, Pecinan Kota Malang, dan 1998. Sedangkan, data sekunder dalam penelitian ini dapat berupa jurnal, artikel, serta bukubuku yang didalamnya memuat metode kritik sastra feminis, konsep politik seksual Kate Millet, ulasan tentang Ratna Indraswari Ibrahim dan karyakaryanya, serta berbagai studi perempuan yang diperlukan untuk membantu analisis.

Teknik pengumpulan data dalam penelitian ini dilakukan dengan beberapa tahap, antara lain: (1) membaca secara menyeluruh dan mendetail (close reading;, (2) menemukan serta menandai hal-hal yang berkaitan dengan politik seksual; (3) mengumpulkan data-data dari berbagai sumber yang dikumpulkan melalui studi kajian pustaka (library reseacrh); (4) melakukan analisis lanjutan terhadap ketiga novel; dan (5) melakukan seleksi terhadap seluruh data, yang bertujuan agar mendapatkan data yang sesuai untuk analisa. Teknik analisis data dalam penelitian ini dilakukan dalam beberapa tahap, antara lain, (1) menyiapkan dan menyusun data-data yang akan dianalisis (baik data primer maupun sekunder), (2) membaca data primer, (3) melakukan coding, (4) memperoleh sebuah deskripsi untuk dianalisis dari data coding yang telah dilakukan pada tahap tiga, dan (5) peneliti melakukan analisis dan interpretasi terhadap semua data yang diperoleh.

\section{HASIL DAN PEMBAHASAN}

\section{Politik Seksual yang muncul dari Kekuasaan dan Rasial}

Tokoh-tokoh perempuan dalam Lemah Tanjung, Pecinan Kota Malang, dan 1998 terlihat "kurang akrab" dengan dunia politik. Ninik dan Purti (1998) harus memiliki "suara" yang "senada" dengan Suwarno sebagai kepala keluarga. Bu Indri dan Gita (Lemah Tanjung) digunakan sebagai "pion" dalam permainan politik beberapa pihak yang memanfaatkan perjuangan murni mereka dalam mempertahankan lingkungan. Anggraeni (Pecinan Kota Malang) seorang perempuan Tionghoa yang begitu ketakutan atas kerusuhan-kerusuhan yang terjadi pada Mei 1998 namun tidak bisa pergi meninggalkan Indonesia tanpa izin suaminya. Semua tokoh perempuan tersebut juga secara terang-terangan menyatakan ketidaktertarikan mereka pada dunia politik.

"Putri merasa Reformasi ini milik Neno dan aktifis lain, bukan milik dia yang lebih suka diam saja di rumah dan menikmati kebersamaan dengan Neno." (2012:183)

"Asrul, kamu tahu, saya tidak suka berpolitik praktis. Apalagi menjadi kebo ijo. Saya ini cuma ingin menjadi teman bu In. Kalau saya dianggap sudah dipolitisasi, satusatunya jalan agar tidak masuk ke pusaran itu, saya harus meninggalkan kota Malang." (2003:372) 
Dunia politik lebih banyak dikuasai oleh laki-laki, perempuan hanya berperan sebagai "penonton" atau "pendukung" lakilaki. Padahal politik merupakan salah satu jalan utama yang dapat digunakan perempuan untuk menghapuskan ketidakadilan seksual. Namun, inferioritas yang terlanjur meresap dalam diri perempuan pada akhirnya membuat mereka pun enggan untuk berpartisipasi di ranah politik.

Terlebih bagi perempuan Tionghoa, yang saat itu menjadi sasaran dan dikambinghitam-kandalam permasalahn politik, mereka tidak mungkin punya kesempatan untuk memasuki dunia politik, karena pemerintah Orde Baru saat itu telah melarang dengan tegas bergabungnya etnis Tionghoa. Para perempuan etnis Tionghoa menerima diskriminasi yang bertubi-tubi karena posisi mereka sebagai "double minority", yaitu terdiskriminasi di dalam masyarakat karena statusnya sebagai etnis Tionghoa dan sebagai perempuan atau seorang istri.

Konstruksi-konstruksi yang telah dibuat oleh negara pada masa Orde Baru yang menjauhkan para perempuan dari dunia politik tersebut kemudian berpengaruh pada kehidupan perempuan di berbagai aspek, yaitu seperti kelas sosial yang erat kaitannya dengan ekonomi dan pendidikan, keluarga serta cinta dan pernikahan yang secara otomatis akan mempengaruhi hubungan sosial mereka dengan masyarakat luas.

\section{Politik Seksual yang Muncul dari Kelas Sosial}

Isu kesenjangan sosial sangat jelas terlihat pada era pemerintahan Orde Baru. Hal ini tentu berpengaruh pada sektor- sektor lain di masyarakat, termasuk bagaimana kelas sosial dapat mempengaruhi seseorang dalam menjalankan peran gendernya yang berujung pada politik seksual. Masyarakat menilai bahwa kelas sosial tinggi umumnya ditempati oleh laki-laki. Sehingga kelas sosial tersebut digunakan sebagai modal kekuasaan mereka. Laki-laki yang tidak bisa mencapai kelas sosial tinggi akan dipandang sebelah mata oleh masyarakat. Sementara, bagi perempuan yang memiliki kelas sosial tinggi mungkin saja bisa "menang" dari perempuan lain, namun hal itu tidak berlaku bagi relasinya dengan lakilaki. Di mana pun kelas sosial perempuan, mereka tetap dianggap sebagai inferior, seorang "istri" yang "ikut" suami.

Novel-novel Ratna menggambarkan permasalahan yang terjadi antara laki-laki dan perempuan maupun perempuan dengan perempuan lain perihal perbedaan kelas sosial. Tokoh Roy (Lemah Tanjung) menggunakan kelas sosialnya untuk dapat menakhlukkan Bu Indri dan Gita, dalam hal bisnis maupun cinta. Tokoh Ninik dan Suwarno serta Putri dan Neno (1998) dapat dikatakan sebagai pasangan beda kelas sosial. Begitu juga dengan Lely dan Gunaldi (Pecinan Kota Malang) yang berbeda suku. Kelas sosial Suwarno dan Neno yang lebih rendah dari pada pasangannya membuat mereka diremehkan oleh masyarakat. Namun, hal ini bukan berarti mereka kehilangan otoritasnya sebagai laki-laki. Ninik dan Putri tidak bisa menukar kelas sosialnya dengan kekuasaan, sehingga mereka tetap berada dalam posisi subordinat. Sama halnya dengan Lely, karena nilai-nilai patriarkal yang sejak kecil telah tertanam begitu kuat dalam dirinya, ia tetap berberan sebagai istri yang mengabdikan diri pada suami meskipun 
berasal dari suku yang lebih tinggi serta memiliki penghasilan sendiri.

"Tentu saja dia merasa tidak bersalah. Pikirnya ini proyek yang merugi karena dia sudah mengeluarkan banyak dana buat kantong pejabat." (2003:251)

“(..) Saya tahu, kamu belum sampai mencintainya. Kamu cuma terseret oleh arus yang besar. Kamu terpesona karena kehidupannya barangkali adalah impian kita bersama." (2003:253)

Sementara itu, karir dan kesibukan yang telah dicapai bu Indri serta kemerdekaan berpikir Banon dan mbak Syarifah membuat Gita (Lemah Tanjung) merasa cemburu. Ninik (1998) iri pada karir dan kesuksesan Farida. Hal ini membuatnya menyadari bahwa selama ini dirinya tidak bisa beraktualisasi di tengah masyarakat karena hanya berkutat di ranah domestik. Lely dan Anggraeni (Pecinan Kota Malang) saling cemburu karena kekuarangan masing-masing. Lely cemburu pada pendidikan tinggi dan kecerdasan yang dimilki Anggraeni. Sedangkan Anggraeni cemburu pada kesuksesan dan kekayaan Lely.

"Perempuan itu kelihatan sangat sibuk. Saya merasa sedikit iri karena pada saat ini saya tidak tahu apa yang harus saya lakukan untuk mengisi waktu." (2003:10)

Ninik hanya ingin mencecap sesuatu yang bukan karena prestasi suaminya. Tiba- tiba ia merasa ada kebosanan dan terkadang dia kepingin sekali ada jeda dalam hidupnya. Cerita Farida tentang dunia seminar, pergi dari satu kota ke kota yang lain, dari satu negeri ke negeri yang lain itu membuat Ninik ingin menjalani kehidupan seperti itu." (2012:28)

\section{Politik Seksual yang Muncul dari Ekonomi dan Pendidikan}

Kelas sosial selalu berkaitan erat dengan pendidikan, karir, dan taraf perekonomian yang dicapai oleh sesorang. Bagi perempuan, memiliki pendidikan tinggi, karir profesional serta mampu mandiri secara finansial diharapkan dapat „menyelamatkan" posisi mereka dan mendapatkan pengakuan dari masyarakat yang sebelumnya selalu memandang perempuan sebagai sosok "kelas dua". Sayangnya realita mengatkan bahwa meskipun memiliki pendidikan tinggi, karir yang cemerlang, serta perekonomian yang mapan perempuan tetap sulit untuk mencapai kesetaraan dengan laki-laki selama konstruksi patriarki masih tetap ditanamkan dalam diri setiap orang dan dinikmati oleh diri setiap perempuan. Namun, hal ini tidaklah sia-sia, karena ini merupakan jalan awal untuk menemukan kesadaran agar terbebas dari ketergantungan mereka pada laki-laki. Meskipun disisi lain, konstruksi "kepala keluarga" dapat digunakan perempuan untuk "menguasai" laki-laki melalui "tuntutan"/"tekanan"/"beban", walaupun sebenarnya hal ini hanyalah proses timbal balik yang tetap berujung opresi pada perempuan. Dan lagi-lagi, hal ini seringkali terjadi karena status perempuan sebagai "istri" yang didefinisikan oleh negara.

Pergeseran pola pikir masyarakat mengenai pentingnya pendidikan bagi perempuan dapat terlihat dari kemunculan tokoh-tokoh dalam tiga novel Ratna. Hampir semua tokoh-tokoh perempuan digambarkan berpendidikan tinggi, 
mencicipi bangku kuliah, mempunyai gelar sarjana bahkan S2 dan S3 dan seringkali mempunyai karir yang bagus, mereka diantaranya adalah: Gita (karyawan bank), $\mathrm{Bu}$ Indri (dosen), Mbak Syarifah (penulis), dan Banon (Lemah 13 Tanjung), Anggraeni (dosen) dan anakanaknya (Pecinan Kota Malang), serta Ninik, Putri, dan Heni (1998).

"Aku tidak ingin masmu galih pulang ke malang, bahkan aku pingin mengirimmu ke amerika sekalipun belum selesai S1. Rasanya suasana belajar disini tidak nyaman lagi. Padahal aku kepingin melihat kau kelas menjadi wanita karir, bukan seperti aku, hanya perempuan di ranah domestik sosial saja." (2012:24)

"Tentu saja ketika mahasiwa, saya menolak ucapan itu. Saya belajar sekuat tenaga dan ikut aktif dalam forum apa pun. Saya tidak suka siapa pun, bahkan Paul sekalipun misalnya, yang berani mengatakan kalau saya tidak bisa apaapa." (2003:89)

"Peran ganda" yang dibebankan oleh pemerintah pada perempuan membuat mereka yang meskipun telah mencapai pendidikan dan karir yang baik, tidak bisa menjalani peran mereka dengan total karena dilarang melupakan "kewajibannya" sebagai seorang "ibu". Hal ini membuat sebagian perempuan memilih sebagai ibu rumah tangga dan menggunakan pendidikan yang telah ia capai untuk mendidik anak, seperti tokoh Ninik dalam novel 1998. Ia harus memendam keinginannya untuk berkarir dan berkontribusi di masyarakat. Dalam novel 1998, Ninik digambarkan sebagai perempuan ideal yang sesuai dengan konsep "ibuisme" negara pada era Orde Baru.
"Sekali lagi ia tidak pernah menyesal hanya menjadi ibu dari anak-anaknya, tapi sungguh ia ingin sekali mempunyai uang dari hasil keringatnya sendiri (...) Ninik hanya ingin mencecap sesuatu yang bukan karena prestasi suaminya." (2012:28)

Lain ceritanya dengan tokoh Gita (Lemah Tanjung) yang menggunakan "ketergantungannya" secara ekonomi untuk "menguasai" suaminya melalui "tuntutan", meskipun ia harus membayarnya dengan mengorbankan keinginannya. Lalu, tokoh Lely (Pecinan Kota Malang) yang menyerahkan kepemilikan aset-aset hasil jerih payahnya pada suami.

"Setelah menikah, sekalipun saya sendiri bekerja, sebagian besar kebutuhan rumah tangga kami ditanggung oleh Paul. Sementara itu, gaji saya untuk kesenangan diri saya sendiri. Tampaknya, saya memang tidak berbuat apa pun yang mungkin punya arti bagiku sendiri" (2003:79)

Dalam ketiga novelnya, Ratna menciptakan tokoh Mbak Syarifah, seorang difabel yang seringkali tidak "tersentuh" dan dianggap sebagai "liyan" oleh masyarakat, berhasil menunjukkan eksistensinya sebagai penulis.

\section{Politik Seksual yang Muncul dari Keluarga dan Hubungan Sosial}

Sebagai kepala lembaga patriarki, keluarga bertugas untuk menanamkan ideologi patriarkal kepada anak-anak. Sayangnya hal ini seringkali justru melalui seorang ibu atau nenek. Penanaman ideologi ini sangat mempengaruhi bagaimana anak-anak bersikap hingga mereka dewasa. 
Dalam beberapa kasus ideologi ini dapat menguntungkan sekaligus merugikan baik untuk laki-laki maupun perempuan, meskipun pada kenyataannya lebih banyak merugikan perempuan. Ideologi ini akan sangat sulit dihapus karena sistem penanam dilakukan secara turun-temurun pada setiap generasi. Dengan demikian, meskipun setelah dewasa mereka mengikuti atau mempelajari kajian perempuan misalnya, jika lingkungan di sekitar mereka tetap memegang teguh dan menerapkan nilainilai patriarki, mereka yang berusaha melawan seringkali justru dianggap "melenceng", bahkan oleh kaum perempuan itu sendiri. Situasi politik dalam pemerintahan Orde Baru juga turut mempengaruhi tersebarnya ideologi patriarkal dan mengakibatkan politik seksual muncul pada keluarga dan masyarakat dengan membentuk "bapakibuisme", yang mana "bapak" adalah sumber kekuasaan, sementara "ibu" adalah mediatornya.

Nilai-nilai patriarkal yang sejak kecil diterima oleh tokoh Gita (Lemah Tanjung), Lely (Pecinan Kota Malang) Ninik (1998) mempengaruhi pola pikir dan cara bersikap dalam memandang diri mereka maupun menyikapi pernikahan. Hal tersebut sangat sulit dihilangkan meskipun mereka pernah mengikuti kajian perempuan, mereka belum sepenuhnya berani melawan normanorma yang ada karena masyarakat akan menentang apa yang mereka lakukan.

“(..) Buktinya, sekalipun usia pernikahan saya dengan Paul sudah hampir empat belas tahun, kadangkadang masih terasa gagap untuk bicara dengan Paul tentang hal yang sebenar-benarnya." (2003:67)
"Aku kecewa dengan keputusan itu...tetapi aku tidak berani memaksa, karena aku harus menghormati orang laki- laki. Maka aku diam saja. Dalam hati aku merasa kecewa..." (2008:82)

"Secara normatif saya adalah istri Paul, yang seharusnya bersama Paul, di mana saja dia berada. Nyatanya? Saya lebih suka tinggal di sini. Maka jika saya bersikap tidak normatif, tetap hidup di Malang bersama Bonet, bukan saja masyarakat yang akan menudingku sebagai istri yang tidak bisa setia, melainkan juga diriku sendiri. (2003:89)

Meskipun demikian, tokohtokoh dalam tiga novel Ratna mulai menyadari bahwa konstruksi dominan untuk laki-laki dan subordinat untuk perempuan tidak boleh diteruskan. Oleh sebab itu, mereka tidak ingin mewariskan nilai-nilai dan stereotipe yang mengarah pada ketidakadilan gender pada anak-anak mereka.

"Paling tidak, saya tidak ingin Bonet hanya belajar tentang peran sosial domestik saja. Apalagi neneknya kerap bilang, manakala saya marah kala dia lupa mengerjakan PR- nya, "Bonet itu cantik. Dia akan jadi pengantin dari laki-laki kaya yang tidak akan bertanya kepadanya tentang LSM, atau apa itu namanya." (2003:91)

\section{Politik Seksual yang Muncul dari Cinta dan Pernikahan}

Relasi antara suami dan istri dalam sebuah pernikahan dapat dikatakan sebagai tempat bersarangnya politik seksual "abadi". Politik seksual yang muncul dalam hubungan pernikahan begitu kompleks. Hal

Jurnal Lakon: Kajian Sastra dan Budaya e-ISSN: 2527-4899; p-ISSN 2252-8954 
ini ditentukan oleh sikap laki-laki maupun perempuan dalam menjalani kehidupan pernikahan, juga dari sejauh mana nilainilai patriarkal telah meresap dalam diri. Konstruksi "suami" dan "istri" yang telah dibuat oleh negara, masyarakat, serta dikukuhkan oleh tradisi dan agama membuat perempuan sulit untuk melepaskan diri dari otoritas lakilaki. Bagi mereka yang memiliki keberanian untuk "melawan" kekakuan ini, mereka akan mendapatkan kemerdekaan, namun harus menebusnya dengan sentimen masyarakat. Batas-batas yang ada dalam ikatan pernikahan, terlebih yang ditujukan untuk perempuan, membuat sebagian dari mereka berani memutuskan untuk tidak menikah demi meraih kemerdekaan diri.

Dalam novel Lemah Tanjung dan Pecinan Kota Malang, Ratna Indraswari Ibrahim menceritakan tokoh Gita (Lemah Tanjung) yang amat merasa terbelenggu dalam pernikahannya. Hal ini karena ia tidak bisa bebas melakukan apa yang ia inginkan sebagai seorang individu.

“(..) Saya jadi berpikir, apakah pilihan saya untuk menikah tidak keliru? Saya seperti dikondisikan olehnya untuk menjadi seperti dia. Ya, saya tahu pendapat umum, istri harus ikut suami. Tapi, dengan begitu, apakah bisa membuat kita merasa bahagia?" (2003:48)

“(..) Lantas, sebuah pikiran meloncat: pernikahan ini sudah membelengguku! Sepertinya tidak bisa menikmati kehidupan privasiku sepenuhpenuhnya." (2003:131)

Selain itu, cerita mengenai perselingkuhan yang mengarah pada isu poligami digambarkan pada dua tokoh laki- laki, yaitu tokoh Paul dengan Sussy serta Gunaldi dengan Atik. Gita (istri Paul) dan Lely (Istri Gunaldi) menyikapi perselingkuhan suaminya dengan cara yang berbeda, meskipun pada akhirnya mereka sama-sama memaafkan suami maasingmasing.

"Kadang-kadang dalam hidup ini diperlukan pengorbanan demi kabaikan kita bersama, demi anakku Bonet. Saya mendinginkan hati saya mendengar nama Susy Graemes terasa begitu mengiris. Saya ingat omongan Mbak Syarifah, cinta itu direbut dan dipertahankan! " (2003:144)

Ratna juga menggambarkan tokoh perempuan yang berselingkuh dan mengarah pada poliandri, yaitu Gita (Lemah Tanjung) dan Anggraeni (Pecinan Kota Malang). Masyarakat menilai bahwa yang berhak poligami adalah laki-laki, sedangkan perempuan yang poliandri dianggap menyalahi aturan. Ketika lakilaki melakukan perselingkuhan maka istri seakan-akan harus memaafkan dan memberi pemakluman sambil instropeksi diri tentang apa yang kurang dari dirinya. Sementara, bagi perempuan yang berani "mendua" akan dianggap sebagai perempuan "nakal".

"Kamu seperti perempuan nakal! Semua orang tahu kamu pacar barunya. Hentikan itu atau kamu memang sudah menjadi perempuan murahan." (2003:253)

"Masya Allah, saya memang perempuan kuno, yang mudah mengekspresikan suasana hati ini. Sungguh, saya sendiri menolak apabila ada perempuan yang bisa mencintai dua laki laki sekaligus. Itu kegilaan yang luar biasa. Padahal, 
norma hanya menyepakati yang bersifat poligamis itu adalah laki-laki." (2003:300)

Ikatan dalam pernikahan yang sulit dilonggarkan membuat tokoh Mbak Syarifah (Lemah Tanjung), Aisah (Pecinan Kota Malang), dan Niken (1998) memutuskan untuk tidak menikah. Mereka menebus rasa kesepian dan cibiran dari masyarakat dengan menjadi perempuan yang sukses dan merdeka.

\section{Bentuk-bentuk Negosiasi yang dilakukan tokoh-tokoh Perempuan.}

\section{Beberapa tokoh-tokoh}

perempuan berani melakukan resistensi dalam tiga novel ini dapat dikelompokkan menjadi dua. Pertama, mereka yang melakukan perlawanan dengan cara pembuktian dan aktualisasi diri, yaitu mereka yang telah mampu mencapai pendidikan tinggi, karir yang cemerlang, serta perekonomian yang mapan, sehingga meskipun pada beberapa kasus mereka masih terdiskriminasi, namun setidaknya mereka telah membangun "peran" dan "status" mereka yang baru ditengah masyarakat. Perlawanan para perempuan dengan cara pembuktian eksistensi ini umumnya masih didukung oleh sebagian besar masyarakat. Berbeda dengan hal yang kedua, yaitu dengan cara pelanggaran norma-norma yang mengikat perempuan, seperti melawan laki-laki, baik ayah ataupun suami, demi mempertahankan keinginan pribadi. Dan juga beberapa perempuan yang berani memutuskan untuk tidak menikah. Perlawanan yang kedua ini umumnya akan menerima sangsi sosial dari masyarakat serta dianggap "liyan".

\section{SIMPULAN}

Penelitian ini menemukan bahwa institusi-institusi pendukung patriarki telah menyebar dalam aspek-apek kehidupan perempuan. Dalam penelitian ini, politik seksual muncul dalam lima aspek, yaitu (1) kekuasaan negara dan rasial, (2) kelas sosial, (3) ekonomi dan pendidikan, (4) keluarga dan hubungan sosial, serta (5) cinta dan pernikahan. Dari semua institusi pendukung patriarki, institus "sosiologi (sociological)" yang mengkonstruksi lakilaki sebagai pemimpin dan kepala keluarga merupakan institusi yang paling sering ditemui dan paling kuat dalam mewujudkan opresi terhadap perempuan. Selain itu, institusi "paksaan (force)" melalui kebijakan atau hukum negara pada masa Orde Baru saat itu sangat mempengaruhi berjalannya sistem patriarki secara menyeluruh di masyarakat. Dalam menghadapi politik seksual, muncul bentuk-bentuk negosiasi dari beberapa tokoh perempuan, antara lain: (1) bertambahnya pengetahuan perempuan dalam bidang politik, (2) tercapainya pendidikan tinggi, (3) karir menjanjikan serta perekonomian yang mapan, (4) adanya kesaran untuk tidak mewariskan nilai-nilai patriarkal kepada generasi berikutnya, (5) adanya perubahan cara pandang terhadap pernikahan, (6) muncul keberanian beberapa perempuan untuk "melanggar" norma yang mengikat. Namun, dalam penelitian ini ditemukan bahwa perempuan berada dalam masalah yang dilematik. Di satu sisi mereka tidak ingin terdiskriminasi, namun merasa takut untuk melawan sistem-sistem patriarki yang sudah mapan di masyarakat. Sementara di sisi lain, mereka merasa perlu untuk melawan segala opresi yang mereka terima, dengan konsekuensi dianggap "melenceng" oleh masyarakat pro- patriarki. 


\section{DAFTAR PUSTAKA}

Arimbi, Diah Ariani. 2009. Reading Contemporary Indonesian Muslim Women Writers: Representation, Identity dan Religion of Muslim Women in Indonesian Fictions. Amsterdam: Amsterdam University Press.

Barker, Chris. 2004. The SAGE Dictionary Of Cultural Studies. London: SAGE Publications.

Barry, Peter. 2010. Pengantar Komprehensif Teori Sastra dan Budaya (Beginning Theory). Yogjakarta: Jalasutra.

Carter, David. 2006. Literary Theory. Herts: PocketEssentials.

Creswell, John. W. 2009. Research Design: Qualitative, Quantitative, and Mixed Method Aproach. Los Angels: Sage Publication.

Djajanegara, Soenarjati. 2003. Kritik Sastra Feminis: Sebuah Pengantar. Jakarta: Gramedia Pustaka Utama.

Ibrahim, Ratna Indraswari. 2003. Lemah Tanjung. Jakarta: PT. Gramedia Widiasarana Indonesia. .2008 .

Pecinan Kota Malang. Human Publishing. .2012. 1998. Jakarta: PT. Gramedia Pustaka Utama.

Michalik, Yvonne \& Budianta, Melani. 2015. Indonesian Women Writers. Berlin: Regiospectra Verlag. Millet, Kate. 2000. Sexsual Politics. Urbana and Chicago: University Of Illinois Press.

Sugihastuti \& Suharto. 2002. Kritik Sastra Feminis: Teori dan Aplikasinya. Yogyakarta: Pustaka Pelajar. Suryadinata, Leo. 2002. Negara dan Etnis Tionghoa. Jakarta: Pustaka LP3ES.

Suryakusuma, Julia. 2011. Ibuisme Negara: Konstruksi Sosial Keperempuanan Orde Baru. Depok: Komunitas Bambu.
Swingewood, Alan \& Laurenson, Diana. 1971. The Sociology Of Literature. London: Paladin.

Tong, Rosemarie Purnam. 2004. Feminist Though: Pengantar Paling Komprehensif kepada Arus Utama Pemikiran Feminis. Yogjakarta: Jalasutra. 